\title{
Barriers to Entry in Italian Political Parties: Understanding Why Party Leaders Hand over Governments to Technical Experts
}

\author{
Paola Bordandini, Rosa Mulè \\ Department of Political and Social Science, University of Bologna, Bologna, Italy \\ Email: rosa.mule@unibo.it
}

Received 20 January 2016; accepted 17 April 2016; published 20 April 2016

Copyright (C) 2016 by authors and Scientific Research Publishing Inc.

This work is licensed under the Creative Commons Attribution International License (CC BY).

http://creativecommons.org/licenses/by/4.0/

(c) (i) Open Access

\begin{abstract}
Why are some party governments suspended and replaced by technical governments? There are surprisingly few answers to this important question in the literature. This article contributes to the literature by analyzing the demographic profiles of the parties' most committed activists, the party delegates. There is very little in the way of comparative, synchronic and diachronic research that seeks to explore similarities and differences in the demographic profile of middle level elites within radically different political and institutional environments. This article aims at filling such void in empirical research. It draws upon an original dataset based on about 4000 interviews to party national delegates of 15 political parties in Italy between 2004 and 2009, and compares the results with those of the first European comparative research of party delegates that dates back to the seventies, the EPPMLE (European Political Parties Middle Level Elites). Our research findings suggest the presence of high entry barriers that prevent young individuals and women fully to participate in the party's life. This demographic bias may be a key factor in accounting for the advent of technical governments in Italy because it dwarfs the possibility that new human capital helps developing innovative party programmes.
\end{abstract}

\section{Keywords}

Demographic Profile of Party Delegates, Technical Governments, Entry Barriers

\section{Introduction}

Technical governments in parliamentary democracies comprise of experts and technocrats whose positions are legitimized by their competences rather than by parliament. The issue has been addressed from multiple pers-

How to cite this paper: Bordandini, P., \& Mulè, R. (2016). Barriers to Entry in Italian Political Parties: Understanding Why Party Leaders Hand over Governments to Technical Experts. Open Journal of Political Science, 6, 205-213. 
pectives. Technocratic governments raise questions about definitions, what exactly is a technocratic government and how does it differ from party government (McDonnell \& Valbruzzi, 2014)? Are technocratic-led governments compatible with democratic accountability? Scholars that focused on the selection of ministerial staff in parliamentary democracies point to new trends of ministerial recruitment from outside the realm of politics (Blondel \& Thiébault, 1991). Others suggest that economic crises favour the appointment to governmental positions of experts from outside the political party system (Centeno \& Silva, 1998; Domínguez, 1997). More recently, the literature on "third-wave" democracies has addressed the weight of institutional factors, such as a semi-presidential system or mixed electoral systems, in the selection of technical-political ministers (Costa Pinto \& Tavares de Almeida, 2009; Protsyk, 2011; Schleiter \& Morge-Jones, 2009). However, as McDonnell \& Valbruzzi (2014: p. 655) recently observed, governments led by technocrats remain a nebulous category, chiefly because theoretical work on technocratic governments is scarce and confusing. These authors define a technocratic-led government as a government where: "a prime minister or a minister is a technocrat if at the time of his/her appointment to government, he/she has never held public office under the banner of a political party; is not a formal member of any party; is said to possess recognized non-party political expertise which is directly relevant to the role occupied in government” (McDonnell \& Valbruzzi, 2014: pp. 657-658).

Using this definition, we note that in Italy the phenomenon of technocratic-led governments has occurred more often than elsewhere, thus "revealing once more its deviance from European parliamentary democracies" (Pasquino \& Valbruzzi, 2012: p. 1). Over the past two decades there have been three technical governments: the Ciampi government (1993 to 1994), the Dini government (1995 to 1996) and the Monti government (20112013). These governments present both similarities and differences. Of the three, the Monti and Dini governments were non-political ones in the true sense, due to their genesis and the connotation of all their members, ministers and undersecretaries. The Ciampi government was indeed born as a government of the President and sustained by a political majority but comprised mainly of members of the party system who held the most important portfolios. On the other hand, whereas the technical government led by Dini was formed to break the deadlock caused by the crisis of the parliamentary majority that had won the elections of March 1994, the Ciampi and Monti governments shared a number of priorities in their agenda. Their formation was justified above all by the threat of an external shock produced by economic and financial crises. The advent of the Ciampi government in 1993 stemmed from a dual challenge: the unsustainability of public finances and a judicially-generated crisis of legitimacy of those political parties that governed during First Republic. The non-political government led by Prime Minister Mario Monti derived from the pressures of the financial crisis in the euro zone.

The central issue, therefore, is the following: in Italy, recourse to technical governments seems to be determined by the inability of parties to take difficult and unpopular decisions in times of crises. Such inability does not exclude that appointments of technical governments may reflect a "strategic retreat” enacted by political parties. In fact, technical governments are not born in opposition to parties, but rather with their support. In the words of Mario Monti, former Italian Prime Minister of a technocratic government, his technical government was a "sexless melding of political influences", i.e. "something that has nothing to do with party politics". Perhaps for this reason, technical governments seem to have better chances for coping with crises because they "pull the chestnuts out of the fire" for the parties and prepare their return onto the scene.

There remains the fact that Italian-style party governments do not seem able to anticipate the occurrence of pre-announced crises; they are not able to cope with them once these crises turn into emergencies. Hence, the following question arises. What is it that dwarfs the ability of parties and their leaders in Italy to cope with crises, pushing them to resort to technical government three times in twenty years? The scholarly debate on technical governments is scant and the issue has received little attention in the literature, with few exceptions (McDonnell \& Valbruzzi, 2014). The problem is complex and multifaceted and this article cannot deal with all the possible explanations regarding the formation of technical governments in parliamentary democracies. Our aim is more limited. We focus on the life of political parties "from within" by exploring the changing demographic profiles of their most committed activists, the delegates to national conventions, drawing upon original data assembled from research carried out at the national conventions of Italian political parties in the 1970s and between 2004 and 2009.

National party delegates are not just simply party members, but activists with a long political militancy. In many cases, these are individuals with social visibility, thanks to their organizational or elective positions in pol- 
itics and local level associations. Therefore they are often focal members of party communities who can shed light on the relationship between parties and society and between local party units and central organization. Indeed, party delegates can be considered privileged witnesses who experience from "within" the parties' transformations induced from without. Hence, their values and attitudes are more stable compared to those of simple members, and this is another reason why they represent a bridge between the old and the new parties in Italy (Bordandini, Di Virgilio, \& Mulè, 2011).

National party delegates, in fact, lie somewhere between a party’s local leadership and its national leadership, and thus can be defined as middle level party elites. According to Niedermayer, "European political parties are internally differentiated organizations. To study their functioning, five types of relevant actors can be distinguished: ordinary party members, local party activists, local party elites, middle level party elites, and party leadership" (1986: p. 253).

National delegates are those individuals who participate in national party conferences and can be considered the party's representatives on the ground. In most cases, grass-roots members elect their representatives at the local level. Local representatives vote for the provincial/state's delegates who, in turn, elect the national delegates. Thus delegates are a crucial link in a party's organizational chain because they constitute a bridge between the party membership and its leadership (Rohrschneider, 1994). It is they, in fact, who must transmit the opinions and moods of members and supporters to the governing bodies and, at the same time, make the party's political line known at the local level (Ignazi, 1989: p. 331).

Middle level elites are a "strategic group" not only because they are the driving force of party organization, but also because they are "individuals who are intensively involved politically, but who do not live off politics" (Bellucci, Maraffi, \& Segatti, 2000: pp. 16-17). However, middle level elites are actors who "expect to become at least semi-professional politicians... they perform roles of linkage-coordination between distinct organizational areas from which they derive the main resources to capitalize in the struggle for organizational power and, in general, in the quest for political influence" (Raniolo, 2011: p. 236). Delegates were traditionally perceived as the privileged pool from which to select a party's leadership and its candidates, especially at the local level. For this reason delegates have been referred to as "The leaders in the Years to Come" (Bordandini, Di Virgilio, \& Mulè, 2011).

Research on delegates and party organizations today is quite different from the past owing to the gradual shift of political parties from civil society to the state (Katz \& Mair, 1995). One consequence is the increasingly marginal role of the party on the ground with respect to the party in central office (and especially to the party in public office), which has rendered analyses on party membership more complex and less salient, whereas surveys on national delegates have taken on a much more significant role. There are mainly two reasons for this increasing significance. First, future leaders usually emerge from within political parties, especially from the group of party delegates (Mulè, 2011). Analysing national delegates allows researchers to acquire a crucial viewpoint, especially in the last twenty years during which parties have undergone profound transformations, with split-offs, mergers and implosions being the rule.

Second, because it appears that surveys on national delegates can be organized much more easily than surveys on party members and party local organizations. Organizational streamlining has prompted parties to reduce efforts on collecting and managing data regarding membership, local party headquarters and official documents. Consequently, at least in Italy, scholars interested in grass roots politics are confronted with outdated if not unreliable data (Ignazi, 2013). The only time parties try to assemble information on their organizations is during their national conferences, which require the activation of all the necessary logistical and organizational procedures to elect and appoint the national delegates.

Party delegates have constituted a tested research field in the literature on political parties. The first comparative research of party delegates dates back to the 1970s, namely the European Political Parties Middle Level Elites Project of the European Election Study (EPPMLE), financed by the Volkswagen Foundation, the European Committee and the European Parliament. After the EPPMLE Project no other systematic research on national party delegates was carried out, except for sporadic surveys on the middle level elites.

Recently, however, a new and broader series of surveys of Italian middle level party elites has been conducted by the "Italian Observatory on the Transformations of Political Parties" which began organizing and carrying out the research project in 2004. Our article draws upon this original data to explore whether barriers to entry in Italian political parties have been kept high, thus dwarfing the possibility that new blood could help developing 
innovative party programmes able to cope with sudden and external shocks, such as an economic crisis.

The article is structured as follows. The next section examines the failure of the new Italian parties, analysing the political earthquake that destroyed the traditional parties in the early 1990s and the chances that arose from it due to the entry of new political parties and competitors. The third section describes the dataset, while the fourth examines the delegates' profiles to observe the extent to which the new parties have lowered barriers to entry by accepting a new generation of leaders. The fifth section offers some concluding remarks.

\section{The Gap between Change and Innovation}

Recourse to technical governments is not a new phenomenon in Italy. It occurred in two different generations of parties: the historical parties that disappeared in 1992-93 and the new parties that were established after 1994, following the electoral reform of 1993 and the creation of Forza Italia by Silvio Berlusconi. What is more, between the Ciampi and Monti governments (1993-2011), the political scenario changed dramatically in both the identity of the single parties and their competitive dynamics. The incompetence of parties, however, remained unchanged and the new parties, after twenty years, also passed the hand to a technical government.

The parties that in autumn of 2011 handed the government over to a technical Prime Minister and ministers were new parties, fruit of a sequence of extinctions, new entries, split-offs and mergers that began in 1993-94 and continued for about two decades. The early 1990s were the starting point of a complex party readjustment process because the old parties that built and shaped the Italian democracy after WWII departed from the scene. These were parties strongly institutionalized and able to significantly control both society and the institutions (Morlino, 1991; Pasquino, 1986). They interacted with a highly structured party system that shaped relationship between parties, social groups and voters. In addition, they performed high-level institutional tasks according to a peculiar mix of partyness of government and of party governmentness (Cotta \& Verzichelli, 2000; Vassallo 1992). These historical parties balanced the many geopolitical and cultural differences that characterized Italian long-term territorial divisions.

The departure of the historical parties from the political scene marked a sharp break with the past. Their legitimacy was seriously undermined by two factors: first, the depletion of symbolic and material resources that had nurtured them for about half a century (Cotta \& Isernia 1996). Second, the “judicial revolution”, which in a few months had put the old party leaders on trial for charges involving acts of political corruption and of improper and unlawful political financing methods (Burnett \& Mantovani, 1998). Thus, the formation of the new Italian parties occurred in a period characterized by widespread and growing disaffection with the traditional political party system and by strong demand for renewal (Morlino \& Tarchi, 1996). In the media and in public opinion these hopes for renewal fuelled demands for electoral reforms, especially a majority system to which miraculous powers were attributed. Reformers were confident that a majority system would free governments from instability and ensure the accountability of elected representatives. They were certain that plurality would guarantee to Italians the opportunity for a direct choice between alternative majorities, as in the United Kingdom, and for a locally exercised selection of and control over the single elected representatives, as in the United States; it never crossed their mind that the result could be, instead, minimal accountability of the elected to the electors, as in the United Kingdom, combined with minimal stability and consistency of the majorities, as in the United States (Katz, 2001: p. 114). There is no doubt that the interplay between expectations for change, the new voting rules and a new party system offered real opportunities for innovation and ample room for manoeuvre to fledgling political leaders. This was the context within which the new parties were formed and the "revolution of the supply of parties” took hold (Di Virgilio, 2010). Silvio Berlusconi became its undisputed leading player. Whether Berusconi's impact and role was innovative, detrimental or scarcely influential, is a matter for further research (Newell, 2009).

Shortly before the 1994 election Berlusconi created Forza Italia and orchestrated a territorially diversified pre-electoral centre-right coalition. This strategy had a dual effect. Firstly, building pre-electoral coalitions meant that the parties went back to playing the party-system game. Secondly, Berlusconi took over the role of leader. Pre-electoral coalitions offered alternative choices for governing the country and began to be sanctioned as such by voters. While the creation of left-wing and right-wing pre-electoral coalitions triggered bipolar competition, the party system remained strongly fragmented (Di Virgilio, 2006).

The re-shaped parties quickly adapted to the new rules, keeping differing strategic objectives in mind. Large parties aimed at maximising votes whereas minor parties aspired to guaranteeing their own survival (Di Virgilio, 
2002). In this framework, strategic competition could exert greater influence than in the past because the decisiveness of elections increased significantly and produced a series of alternating political forces in power.

Surprisingly, however, such new political scenario did not affect the parties' ability to innovate. In the Italian tradition, parties had always been crucial players of the political system but rarely acted as agents of innovation. Exceptions were the Fascist Party, in a non-democratic context, and those governments in office immediately after WWII (Cotta, 1996). Moreover, even in these cases parties focused on distributive policies, leaving aside difficult decisions of redistributive politics that are necessary in times of economic-financial crises.

If innovation was not a feature of traditional Italian party elites, things seemed no better when new parties and leaders came to the fore after 1993-1994. The construction of pre-electoral alliances helped the formation of coalitions capable of winning elections, but not of governing. Furthermore, the new parties were organizationally weaker than their predecessors. Several terms were coined to describe such parties. They were either called "personal parties", in the sense that they were put together by one person; or the "President party", if characterized by a charismatic leadership, such as Forza Italia (Calise, 2011). Other parties seemed incapable of expressing leadership skills. Most notably, the former Communist Party in order to succeed resorted to Romano Prodi, a leader external to the party hierarchy.

The presidentialization of politics is not a trend exclusively related to Italian parliamentary democracy. Research finings indicate that there has been a strengthening of the decision-making autonomy of party leaders with respect to the party organization owing to the mediatisation of politics (Palladino, 2013; Poguntke \& Webb, 2005).

That said, the new parties proved incapable of meeting the expectations for change and inept at putting to good use the room for manoeuvring that opens in times of fluidity, handing over the reins to the team of technocrats led by Monti in 2011 (Bosco \& McDonnell, 2013). Yet these parties had at times enjoyed a broad mandate, including the centre-right governments led by Berlusconi which in 1994 and in 2011 resigned in favour of the technical governments of Dini and of Monti.

These events can be examined under different perspectives. In this article we explore the demographic profile of party delegates to throw light on what seems to be a puzzling failure of the new Italian political elite.

\section{The Dataset}

National party delegates have traditionally represented a central segment of a party's organizational framework. While party transformations in the last decades may have diminished somewhat the importance of this segment, it nevertheless remains a significant core for party politics research. A focus on party delegates is especially important if we wish to examine more closely the linkage between parties and society, "participatory" and "policy-responsive” linkages (Lawson, 1980; Merkl, 2005).

It is worth noting that national party delegates are not merely members, but activists with a long history of political militancy. In many cases, they enjoy organizational or elected positions at local and regional levels. As such, they represent nodal elements of the party community, capable of shedding light on the relationships between parties and society and between local and central party organizations. What is more, party delegates are privileged witnesses because they experience from within the transformations of the parties induced from without. Their opinions, values and attitudes are, therefore, more elaborate and more stable than those of grassroots members. In many cases, moreover, they represent a bridge between the old and the new parties.

Thus, by examining if the delegates' demographic profile of the new parties is similar or different from the delegates of the old parties, we acquire valuable information that can shed light on current changes. Middle level party elites, therefore, remain a crucial point of observation, especially given the party transformations of the past twenty years, in which split-offs, mergers and extinctions have been the rule (Bordandini \& Di Virgilio, 2009; Bordandini, Di Virgilio, \& Mulè, 2011).

This article draws upon data gathered from 4,126 interviews of national party delegates at 17 national conventions (of 15 different parties) that took place between 2004 and 2009. Data collection was carried out by means of a structured self-completion questionnaire distributed during party conventions (except for the Verdi Party [Greens], for which a postal survey was organized right after their national convention). The questionnaires where split in two parts, one common to all parties and one specific to each party. Regrettably, we were not authorized to carry out the survey at the founding convention of Popolo delle Libertà (PDL) (Rome, 27-29 March 2009) and at the national convention of the Lega [League] held in June 2012. No sampling plan was needed because we carried out a survey on the entire population by distributing questionnaires to all conference 
participants. $^{1}$

\section{Comparing Delegates' Profiles: 1980-2009}

In view of the political and institutional changes described in Section 2, the destructuring of the Italian party system could have, and perhaps should have, generated a ruling class radically altered in its demographic profile. One could have expected the opening of opportunities for young people and women. Indeed, it is young people within a political organization who have the time and resources, as well as the energy, enthusiasm and willingness for change. And it is women, traditionally under-represented in political parties, who can contribute new visions for change and innovation. Thus, it is reasonable to ask if the profile of the middle level elites of the new parties actually meets these expectations.

There is very little in the way of comparative, synchronic and diachronic, research that seeks to explore similarities and differences in the demographic profile of middle level elites within radically different political and institutional environments. In this section we aim at filling such void in empirical research by comparing a number of variables from surveys on delegates of Italian political parties in two different periods, the end of the 1970s and the first decade of the new millennium.

Unfortunately, it is not possible to investigate the characteristics of all the delegates of the past thirty years, partly because some of the major political parties of the post-war period have now disappeared, e.g. the Democrazia Cristiana, and partly because data are not available. We compare political parties according to their ideological proximity, that is, to their belonging to a "spiritual family".

We examine whether and how the delegates' demographic profile of different "spiritual families" has changed during the three decades. We expect that the political and institutional changes as well as the participation of women in the labour market have increased the percentage of women and lowered the average age of the middle level elites. These are significant indicators of change, not only of the relationship between parties and society, but of the parties' willingness to accept new energies as well.

Starting with gender, the data presented in Table 1 show that the political alignments of left, centre and right have seen an overall increase in the quota of women from the late 1970s up to 2009. There are, however, a number of notable exceptions, such as the persistence of a strong gender imbalance in UDC, not dissimilar to that found for the delegates of DC in 1979, and the drop of 15 percentage points in the quota of women in PRC compared to PCI. Note the growth in the percentage of women among the delegates of DS (43\%) compared to PCI (37\%), the former party is an outgrowth of the latter. The increasing percentage of women delegates in the DS confirms the trend that began in the 1980s and that was recently encouraged by modifications to the party

Table 1. Party delegates by gender and age (1979-2009) (percentages).

\begin{tabular}{|c|c|c|c|c|c|c|c|c|c|c|c|c|}
\hline & \multicolumn{3}{|c|}{ Left } & \multicolumn{5}{|c|}{ Center } & \multicolumn{4}{|c|}{ Right } \\
\hline & PCI & PRC & DS & DC & Margherita & UDEU & UDC & FI & MSI & AN & Destra & MSFT \\
\hline & 1989 & 2005 & 2007 & 1979 & 2007 & R 2005 & 2005 & 2004 & 1979 & 2009 & 2008 & 2004 \\
\hline \multicolumn{13}{|l|}{ Gender: } \\
\hline Men & 63 & 78 & 57 & 95 & 78 & 89 & 93 & 80 & 94 & 90 & 82 & 90 \\
\hline Women & 37 & 22 & 43 & 5 & 22 & 11 & 7 & 20 & 6 & 10 & 18 & 10 \\
\hline Total & 100 & 100 & 100 & 100 & 100 & 100 & 100 & 100 & 100 & 100 & 100 & 100 \\
\hline Age: & & & & & & & & & & & & \\
\hline Up to 35 & 8 & 37 & 28 & 14 & 22 & 19 & 17 & 18 & 37 & 34 & 24 & 38 \\
\hline $35-35$ & 43 & 22 & 18 & 40 & 18 & 21 & 23 & 24 & 22 & 20 & 24 & 18 \\
\hline $46-55$ & 34 & 28 & 29 & 30 & 26 & 34 & 25 & 24 & 23 & 23 & 29 & 28 \\
\hline Older than 55 & 15 & 13 & 25 & 16 & 23 & 26 & 36 & 34 & 18 & 24 & 22 & 17 \\
\hline Total & 100 & 100 & 100 & 100 & 100 & 100 & 100 & 100 & 100 & 100 & 100 & 100 \\
\hline Average age & N/A & 41 & 46 & 45 & 46 & 49 & 49 & 49 & 42 & 44 & 45 & 42 \\
\hline
\end{tabular}

Sources: PCI in Ignazi (1992) for gender and Accornero \& Magna (1989) for age (the classification in this case is different: up to 29 years-of-age; 30 - 39; 40 - 49; 50 - 59. Data for DC and MSI, in Ignazi, Mancini, \& Pasquino (1981); for PRC, DS, Margherita, UDEUR, UDC, FI, AN, La Destra, MSFT, in Bordandini et al. (2011).

\footnotetext{
${ }^{1}$ All information relating to the surveys on the party delegates carried out by the Italian Observatory on the Transformations of Political Parties are gathered in the book series “Delegati di partito” published by Clueb, Bologna (Bordandini \& Di Virgilio, 2009-2013). The national party delegates' research project was part of an inter-university research program (PRIN), co-funded by the Italian Ministry of Education, University, and Research and the four universities involved: Florence (unit coordinated by Marco Tarchi, who was also the PRIN's national coordinator), Bologna (unit coordinated by Aldo Di Virgilio), Cosenza (unit coordinated by Francesco Raniolo), and Trieste (unit coordinated by Anna Bosco). The Bologna research group-led by Aldo Di Virgilio and Paola Bordandini-has focused its research on party delegates since 2004 and organized, in collaboration with the other PRIN research units, the data collection during the national conferences.
} 
statutes. In fact, as reported by Accornero \& Magna (1989) in the sample survey on delegates at the PCI convention in 1986, women comprised about $24 \%$ of the total. In general, the enlargement of the gender quotas is a signal of greater openness of party organizations, although the data indicate that women are still significantly under-represented.

One could conjecture that these results are linked to specificities of the Italian political culture. However, comparative research reveals that women are under-represented in all countries, not only in Italy, with more or less pronounced differences from country to country (Krook \& Childs, 2010). As is well known, however, the proportion of female politicians is lower in Italy than in most other European countries (Guadagnini, 1993: p. 175). The lower proportion of women in Italy could be attributed to the fact that the political mobilization of women in the 1970s and 1980s was channelled more into social movements, rather than into membership in political parties. In general, it seems that there is persistence of political socialization problems associated to weak incentives in favour of a party career.

As far as the age of the delegates is concerned, one must keep in mind that a political career has always required a long period of time. In almost all bureaucratic and political organizations access to middle-upper levels is achieved over a long timeframe. The main reasons are to be found both in the formal rules (for example, minimum age requirements) and in the need to become familiar with the culture of the party organization. This allows individuals to communicate with other members by means of a codified language, which is learned and mastered only over time. For these reasons, the average age of middle-level party officials is often high.

However, one could have expected an increased influx of young people into party organizations after the political earthquake of the early 1990s, with the formation of the so-called Second Republic. As mentioned above, such parties were newly constituted political entities, in principle more open to younger generations since they possess less solid and sticky internal procedures and hierarchies. Table 1 shows that things are not quite so. In the 1970s the average age of middle-level party officials was approximately 44 years of age (Ignazi et al., 1981). After three decades, we still detect a substantial stability within the new parties, with an average age between a minimum of 41 years-of-age (PRC) and a maximum of 49 years of age (UDC). The average age of delegates of centre parties is equal to, or less than, that of delegates of other parties.

At a first glance, the organizational renewal of political parties does not seem to have been aided by the entry of younger middle-level party officials. As we know, however, the arithmetic mean is sensitive to extreme values and, therefore, it is worth dwelling on the distribution in age brackets. Of notable interest is that PRC, AN, MSFT, as was the case with MSI in the past, stand out for the fact that they can claim a high percentage of young delegates. Almost one third of these parties' delegates declare an age of 35 years or less. This over-representation of young people within the more ideological parties, in the First as in the Second Republics, is consistent with the literature that identifies a concentration of young people among the members of radical parties (Kitschelt, 1989).

Lastly, it is surprising that the share of 55-and-over is greater in the parties of the Second Republic, with the exception of the radical parties, PRC and MSFT. If the gap in DC during the 1970s between the youngest (less than 35 years of age) and the oldest age bracket (more than 55 years of age) was of only two percentage points, it is remarkable that in the post-DC heirs, in particular UDC and UDEUR, the differences are more pronounced (7 and 19 points respectively). Our results indicate that organizational renewal in the parties of the new Millennium has neglected the recruitment of young blood. The data show an imbalance in the relationship between generations to the detriment of young people. Overall, the picture that emerges is one of a political class that prefers to protect acquired positions, rather than to invest in the future. It points to low generational turnover and, therefore, to little or no interest with regard to new generations.

What is more, our findings indicate that about one out of two delegates of the third millennium was already a member of a party of the First Republic. This suggests that the political socialization of middle-level party officials is strongly affected by their experience during the 1980s. Given these data, one can reasonably assume that the marginalization of young people in the party hierarchies of the Second Republic is a significant factor in understanding the inability of party leaders to propose an innovative political project capable of responding to international economic challenges.

The scant importance attributed to young people is also connected to the institutional barriers raised against their entry into politics. Billari (2007) presents recent studies that show Italy in last place among the main European countries with regards to the minimum age for eligibility to the Upper and Lower Houses of Parliament. For example, it is not possible to elect individuals who are younger than 40 to the Senate. 
The data suggest that the barriers are not only institutional, but cultural as well. Explorations of the past three legislatures show that the number of young senators (less than 50 years old) is dropping rather than increasing. From 96 in the fourteenth legislature to 74 in the fifteenth and down to 32 in the sixteenth! These figures point to the surprisingly limited interest of the Italian political class in investing in the future of the country.

\section{Conclusion}

This article aimed at shedding light on some of the reasons behind the advent of technical governments in Italy. Comparing data from surveys carried out during the national conventions of Italian parties at the end of the 1970s and between 2004 and 2009, our research focused on the socio-demographic profiles of the middle-level party elites.

Our findings are surprising. Despite the political earthquake of the mid-1990s, middle level party elites have maintained the same socio-demographic profile. Women continue to be largely under-represented and, in certain cases (PRC), they are even more under-represented than before. Moreover, the average age has remained unchanged and, what is worse, in some parties (UDC and UDEUR) the older cohorts have grown. These results are disturbing. The persistent discrimination of women as well as of younger generations dwarfs both the resources and the innovation potentially offered by these social groups, weakening the capacity for renewal of the political leadership. Our research findings suggest that political parties should lower barriers to entry if they wish to develop better and innovative plans and projects for the future.

\section{References}

Accornero, A., \& Magna, N. (Eds.) (1989). Il nuovo Pci: Due congressi a confronto. Politica ed Economia, Fondazione Cespe, 6, 1-16.

Bellucci, P., Maraffi, M., \& Segatti, P. (2000). PCI, PDS, DS. La trasformazione dell'identità politica della sinistra di governo. Roma: Donzelli.

Billari, F. (2007). Il blocco generazionale della politica italiana. Il Mulino, 5, 795-804.

Blondel, J., \& Thiébault, J. L. (Eds.) (1991). The Profession of Government Minister in Western Europe. London: MacMillan. http://dx.doi.org/10.1007/978-1-349-11395-8

Bordandini, P., \& Cartocci, R. (2011). La cultura politica dei delegati nazionali di partito. Polis, Special Issue, 2, $171-204$.

Bordandini, P., \& Di Virgilio, A. (2009-2013). I partiti italiani a congresso. Ricerche sui delegati (Book Series). Bologna: Clueb.

Bordandini, P., Di Virgilio, A., \& Mulè, R. (2011). I leader degli anni a venire. Atteggiamenti e opinioni dei delegati di partito in Italia. Polis, Special Issue, 2, 159-169.

Bosco, A., \& McDonnell, D. (2013). The Monti Government and the Downgrade of Italian Parties. In A. Bosco \& D. McDonnell (Eds), From Berlusconi to Monti (pp. 37-56). New York: Berghahn.

Burnett, S. H., \& Mantovani, L. (1998). The Italian Guillotine. Operation Clean Hands and the Overthrow of Italy's First Republic. Lanham: Rowman \& Littlefield.

Calise, M. (2011). Il partito personale. Roma-Bari: Laterza.

Centeno, M. A., \& Silva, P. (Eds.) (1998). The Politics of Expertise in Latin America. New York: St. Martin’s Press. http://dx.doi.org/10.1007/978-1-349-26185-7

Costa Pinto, A., \& Tavares de Almeida, P. (2009). Portugal: The Primacy of “Independents”. In K. Dowding, \& P. Dumont (Eds.), The Selection of Ministers in Europe: Hiring and Firing (pp. 147-158). London: Routledge.

Cotta, M. (1996). La crisi del governo di partito all'italiana. In M. Cotta, \& P. Isernia (Eds.), Il gigante dai piedi d'argilla (pp. 11-52). Bologna: Il Mulino.

Cotta, M., \& Isernia, P. (Eds.) (1996). Il gigante dai piedi d’argilla. Bologna: Il Mulino.

Cotta, M., \& Verzichelli, L. (2000). From “Constrained” Coalitions to Alternating Governments? In W. C. Müller, \& K. Strøm (Eds.), Coalition Governments in Western Europe (pp. 433-497). Cambridge: Cambridge University Press.

Di Virgilio, A. (2002). L’offerta elettorale. La politica delle alleanze si istituzionalizza. In R. D’Alimonte, \& S. Bartolini (Eds.), Maggioritario finalmente? La transizione elettorale 1994-2001 (pp. 79-129). Bologna: Il Mulino.

Di Virgilio, A. (2006). Dal cambiamento dei partiti all'evoluzione del sistema partitico. In L. Morlino, \& M. Tarchi (Eds.), Partiti e caso italiano (pp. 173-206). Bologna: Il Mulino.

Domínguez, J. (Ed.) (1997). Technopols. Freeing Politics and Markets in Latin America in the 1990s. Pennsylvania, PA: 
Pennsylvania University Press.

Guadagnini, E. (1993). A “Partitocrazia” without Women. The Case of the Italian Party System. In J. Lowenduski, \& P. Norris (Eds.), Gender and Party Politics (pp. 168-204). London: Sage.

Ignazi, P. (1989). Il polo escluso. Profilo del Movimento Sociale Italiano. Bologna: Il Mulino.

Ignazi, P. (1992). Dal Pci al Pds. Bologna: Il Mulino.

Ignazi, P. (2013). Bussate e... non vi sarà aperto. Sulla difficoltà di fare ricerca nei partiti italiani a livello locale. In P. Ignazi, L. Bardi, \& O. Massari (Eds.), Non solo Roma. Partiti e Classi Dirigenti nelle Regioni Italiane (pp. 337-353). Milano: Università Bocconi Editore.

Ignazi, P., Mancini, U., \& Pasquino, G. (1981). Omogeneità e diversità nei quadri intermedi (Dc, Msi, Pdup, PSDI). Biblioteca della Libertà, 79, 201-251.

Katz, R. (2001). Reforming the Italian Electoral Law, 1993. In M. P. Wattemberg (Ed.), Mixed-Member Electoral Systems. The Best of the Two Worlds? Oxford: Oxford University Press.

Katz, R., \& Mair, P. (1995). Changing Models of Party Organization and Party Democracy: The Emergence of the Cartel Party. Party Politics, 1, 5-28. http://dx.doi.org/10.1177/1354068895001001001

Kitschelt, H. (1989). The Logic of Party Formation. Ithaca, NY: Cornell University Press.

Krook, D., \& Childs, S. (Eds.) (2010). Women, Gender and Politics. A Reader. Oxford: Oxford University Press.

Lawson, K. (1980). Political Parties and Linkage. In K. Lawson (Ed.), Political Parties and Linkage: A Comparative Perspective (p. 410). New Haven, CT: Yale University Press.

Merkl, P. H. (2005). Linkage, or What Else? The Place of Linkage Theory in the Study of Political Parties. In A. Römmele, D. M. Farrell, \& P. Ignazi (Eds.), Political Parties and Political Systems: The Concept of Linkage Revisited (p. 181). Westport, CT: Praeger.

McDonnell, D., \& Valbruzzi, M. (2014). Defining and Classifying Technocrat-Led and Technocratic Governments. European Journal of Political Research, 53, 654-671. http://dx.doi.org/10.1111/1475-6765.12054

Morlino, L. (Ed.) (1991). Costruire la democrazia. Bologna: Il Mulino.

Morlino, L., \& Tarchi, M. (1996). The Dissatisfied Society. Protest and Support in Italy. European Journal of Political Research, 30, 41-63. http://dx.doi.org/10.1111/j.1475-6765.1996.tb00667.x

Newell, J. L. (2009). The Man Who Never Was? The Italian Transition and 2008 Election. Journal of Modern Italian Studies, 14, 395-412. http://dx.doi.org/10.1080/13545710903281862

Palladino, N. (2013). Presidenzializzazioni’: L’Impari lotta per la leadership fra Presidente della Repubblica e Presidente del Consiglio. Proceedings of the Annual Conference of the Società Italiana di Scienza Politica, Florence, 11-13 September 2013, 1-15.

Poguntke, T., \& Webb, P. (2005). The Presidenzialization of Politics. New York: Oxford University Press. http://dx.doi.org/10.1093/0199252017.001.0001

Protsyk, O. (2011). Semi-Presidentialism under Post-Communism. In R. Elgie, S. Moestrup, Y.-S. Wu (Eds.), Semi-Presidentialism and Democracy (pp. 98-116). London: Palgrave MacMillan.

Rohrschneider, R. (1994). How Iron Is the Iron Law of Oligarchy? Robert Michels and National Party Delegates in Eleven West European Democracies. European Journal of Political Research, 25, 207-238. http://dx.doi.org/10.1111/j.1475-6765.1994.tb00418.x

Schleiter, P., \& Morgen-Jones, E. (2009). Constitutional Power and Competing Risks: Monarch, Presidents, Prime Ministers and the Termination of East and West European Cabinets. American Political Science Review, 103, 496-512. http://dx.doi.org/10.1017/S0003055409990062

Vassallo, S. (1992). Il governo di partito in Italia (1943-1993). Bologna: Il Mulino. 